\title{
Embedded Structure of Oracle Night as a Metafiction
}

\author{
Hui Ni \\ Department of English, Heze University, Heze 274000, Shandong, China
}

\begin{abstract}
As one of America's most creative and outstanding postmodernist writers, Paul Auster's novels have received worldwide popularity. His masterpiece Oracle Night was written in 2003 when the literary postmodernism has boomed and metafiction has become a typical postmodernist writing model. This paper aims to study the embedded structure of his Oracle Night, which has been, in part at least, neglected by literary criticism both in China and in foreign countries. Based on detailed textual analysis, the study describes the structural degrees and the corresponding relations between each.
\end{abstract}

Index Terms—Paul Auster, metafiction, embedded structure, narrative, structure

\section{INTRODUCTION}

Often regarded as a postmodernist writer, a default classification due to his experimental techniques and ironic posturing, Paul Auster (1947-) is noted for his idiosyncratic work, which resists simple categorization. His experimentation in writing techniques such as the handling of narrative point of view, and the controlling of narrative time, multilayer narratives, as well as metafictionality, but he is still not widely known, especially to Chinese people. The present paper takes metafictional structural uniqueness as the research topic, so the theoretical background of the research is essential and fundamental to be offered in the first place (Ni, 2012).

Metafiction is a mode of writing within a broader cultural movement often referred to as postmodernism. As Patricia Waugh puts it,

"Metafiction is a term given to fictional writing which self-consciously and systematically draws attention to its status as an artifact in order to pose questions about the relationship between fiction and reality. In providing a critique of their own methods of construction, such writings not only examine the fundamental structures of narrative fiction, they also explore the possible fictionality of the world outside the literary fictional text." (Patricia Waugh, 1984, p. 2)

Several Chinese critics have also generalized some features of metafictional narration from different perspectives ${ }^{1}$. To sum up, metafiction covers the following six major characteristics: juxtaposition of narrative and commentary discourses, open form, parody, fragmented collage, blurring of reality and fiction, random sequences of time and place. These elements provide the reader with various perspectives through which the reader is able to better read and appreciate metafictional narratives $(\mathrm{Ni}, 2012)$.

As for the study of narrative structure, it can be traced back to Aristotle. Since then, many literary critics have carried out further study on the issue. Although some literary critics have made some tentative efforts to give it a definition, it is actually not such an easily definable term as it sounds to be. According to Onega, there are two types of narrative structure, both of which are related to narrative level. One of them is the horizontal structure, which regards the narrative as "the representation of a series of events," and so "these events can be studied according to their position with respect to each other" (Onega, 1996, p. 5). The other type is the vertical one, which is shaped by the embedded point of view, or simply speaking, the embedded narrations of similar basic story. If we put it in another way, narrative structure can also be divided into the following sub-type, that is, linear narrative structure and non-linear narrative structure, which actually mean the same as horizontal and vertical structure. A non-linear narrative usually does not proceed in a straight line and does not follow the step-by-step fashion, such as where an author creates a story's ending before the middle is finished. Linear narrative structure is just the reverse, in which narrative proceeds smoothly in a straight line. And metafictional structure can be seen as a sub-type of the vertical or non-linear narrative structure.

Studies on Oracle Night in the west are mainly divided into two aspects. The first is its style and narrative method. The essay "A Fiction about Fiction-on Auster's Oracle Night" tells us that the novel is a piece of fiction about fiction, indicating that it is a metafiction and he also analyzes the features presented in the metafiction. In the dissertation "The Teller's Tale: Text and Paratext in Paul Auster's Oracle Night (2007)"2, Richard F. Patterson says that in Paul Auster's

\footnotetext{
${ }^{1} \mathrm{Hu}$ Quansheng, British and American Postmodernist Fiction: Reseach into Narrative Structure (Shanghai: Fudan University Publishing House, 2002, pp.30-41.

${ }^{2}$ Gérard Genette defines "paratext" in Paratexts: Thresholds of Interpretation (Cambridge: Cambridge UP, 1997) as those things in a published work that accompany the text, things such as the author's name, the title, preface or introduction, or illustrations. Genette states "More than a boundary or a sealed border, the paratext is, rather, a threshold." It is "a zone between text and off-text, a zone not only of transition but also of transaction: a privileged place of pragmatics and a strategy, of an influence on the public, an influence that [...] is at the service of a better reception for the text and a more pertinent reading of it". He further describes paratext as "a fringe of the printed text which in reality controls one's whole reading of the text".
} 
work narrators tell both their own stories and the stories of others, but the weight is attached to the interface between life and death and on the fragility of human identity. Auster often employs the paratext, an alternative narrative which seems far from the main text but parallel to it in important ways. The second is on the genre of the novel. Most of Paul Auster's works are postmodernist genre with a flavor of detective stories. Brendan Martin's Paul Auster's Postmodernity (2008) states that Paul Auster has become a mature postmodernist writer after he published The New York Trilogy and Oracle Night. In the former book, the author investigates Auster's literary postmodernity in relation to a full range of his factual and fictional writing. He remarks:

"Auster invariably blurs elements of fact and fiction within his narratives, and the majority of his fictional protagonists appear to be versions of Auster [...] In his writing, he highlights the continual presence of random and arbitrary happenings. His conception of chance, confirms his status as a self-consciously postmodern author." (Brendan Martin, 2008, p. 6)

First of all, Oracle Night moulds a protagonist as a writer who creates stories. The writer is Sidney Orr, 34 years old, semi-recovered from a never-quite-specified, nearly-fatal illness, whose will to write has gone watery until he buys an exotic notebook in a stationery store in his Brooklyn neighborhood. The instant this notebook is purchased, stories begin to proliferate, many of which in the footnotes crop up from the bottom of the pages with still more stories, an entire luxuriant jungle of narratives. Orr starts writing a novel in the notebook about an editor with a resemblance to Orr himself who discovers a long-lost novel. Orr's own story unfurls in various complicated ways. There is a screenplay about time travel. There is another older writer, a mentor of Orr's, with stories of his own. Orr is endlessly dissolving into other characters and other stories, not sure whether he is writing a book already written (Ni \& Lian, 2012).

In the second place, other stories happening at different levels are within the basic story. As the novel indicates, it consists of several stories. In a novel of just over 200 pages, we read such a great pile of stories, detailedly, stories about Sidney Orr, Nick, Flagg, Eva, Grace, John Trause, Jacob, Edward, and the time machine. Oracle Night is multi-layered, with story wrapped within story, each story somehow interlinked with the next so that the multitude of fictions chime together in unexpected ways, investing the whole with an almost choral quality, even if that quality can be cacophonous and disturbing. All the stories actually happen at the same time. Voice competes with voice, character with character, and all is so tightly controlled and so technically accomplished that the reader, taken deeply within the fiction, can not discern which part of the novel is fictional and which part is of reality. Finally, the reader loses the sense that it is indeed just a fiction.

Thirdly, the narrator indicates him or herself as the author of the story every now and then on purpose. For example, the narrator, Sidney Orr, frequently claims that he is the author of the story in the novel.

As Kate Liu ${ }^{3}$ says, "Contemporary author Paul Auster has made metafiction the central focus of his writing and is probably the best known active novelist specializing in the genre." And Oracle Night should be fundamentally analyzed as a metafiction.

From the perspective of structure, Oracle Night is a novel which narrates "a story within a story within a story within a story again," which is called Multi-narrative structure, or Embedded Structure. The novel is made up of many stories, and each of which is not necessarily connected with each other. Though only working as fragments, they indeed help to integrate the whole story with certain techniques. And in terms of structure, it can be called Fragmented Structure of Metafiction.

Authors of metafiction usually defy narrative levels by commenting on writing as intruders, involving his or herself with fictional characters, directly addressing the reader or openly questioning how narrative assumptions and conventions transform and filter reality, and finally trying to deny the existence of singular truths or meanings. Some common metafictional approaches contain: a novel in which a writer creats a story, a novel or other work of fiction within the novel or narrative footnotes, which make the story move on while commenting on it. On the whole, if we analyze the features and devices of metafiction in this perspective, we can treat it as work-within-the-work technique, which is also called multi-narrative structure or Embedded Structure. Prince defines "embedded narrative" as "a narrative within a narrative" (Prince, 1988, p.25). To be specific, Oracle Night can be analyzed through the angle of narrative degrees.

A metafiction often contains stories in which two or more narrators weave different discourses. And we call the basic story local basic story. When local basic story contains the crucial events of the basic story, the different discourses built on it are liable to be closely related with the theme. This type is the prototypical multi-layered narrative in our study. But these narrator's discourses may be related with each other in many ways in narratives, which implicates embedded structures.

Story-telling can occur at many different levels. Any narrative is made up of little narratives (Prince, 2003) and the situation of embeddedness, indeed, is the central structural characteristic of all narratives. To quote Bal (1986, p.143), "the narrative text constitutes a whole, into which, from the narrator's text, other texts may be embedded". As Barth (1981) puts it, there are tales within tales within tales, which provides a general framework which can easily be adapted to more complex circumstances. One such circumstance appears when a character in a story begins to tell a story of his or her own, creating a tale within a tale. The original narrative now becomes a "frame" or "matrix" narrative, and the story told by the narrating character becomes "embedded". (Bal, 1981)

\footnotetext{
${ }^{3}$ Kate Liu, Associate Professor, English Department of Fu Jen Catholic University, Taiwan.
} 
Gérard Genette(1980) has illustrated the basic features of embedded structure with the help of a simple drawing using stick-figure narrators and speech-bubble narratives. In Graph (a) below, narrative A contains narrative B, and they belong to the first and second narratives respectively. Another more specific and accurate way to explain this phenomenon is the "Chinese-boxes models",

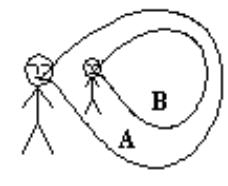

a.

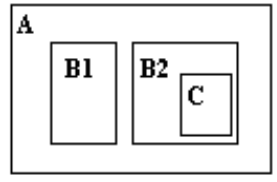

b.

Graph.1

In graph (b) above, A, B1/B2, and C stands for the first, second and third-degree narrative respectively. In Oracle Night, both of the two kinds of styles are applied, or we can say style (b) is a more specific one. This paper will analyze the embedded structure of Oracle Night to reveal the structural degrees, the relationships and the effects of different narrative degrees.

\section{StRuCtural DegreEs}

According to Nelles' classification of narratives, there are two kinds of narrative structures, namely Horizontal or One-layered Narrative and Vertical or Multi-layered Narrative (Two-layered Included). Oracle Night belongs to the second kind.

To give a clearer understanding of embedding, Rimmon-Kenan (1983, p.91) states the following.

"A first-degree narrative is a narrative that is not embedded in any other narrative; a second-degree narrative is a narrative that is embedded in a first-degree narrative; a third-degree narrative is one that is embedded in a second-degree narrative, and so on. Both the second-degree narrative and the third-degree narrative are hypo-narratives or embedded narratives."

The synonym of "matrix" narrative is "First-degree narrative", while "embedded narrative" includes the "second-degree narrative" and "third-degree narrative" (Rimmon-Kenan, 1983). Since the present paper mainly talks about the structural features of Oracle Night, stratification of structural degrees is regarded. Oracle Night is built up of short units - stories and newspaper clippings (both fictional and factual). After reconsideration, it can be revealed that there are some rules in the arrangement of the stories. There are all together seven stories in the novel which can be divided into several degrees so as to form a co-relationship between different stories.

\section{A. First-degree Structure}

A first-degree structure is independent, that is, it is not embedded in any others. The first-degree narrative structure (Rimmon-Kenan, 1983) is about the reality. To put it in another way, it is the story about the protagonist "I" including "my" personal information, family, social relations with John Trause - another writer and friend and the buying and using of the "blue Portuguese notebook" as well as the things that follow.

Auster's leading character, Sidney Orr, is a successful Brooklyn author who finds himself in a writing dry spell after a mysterious accident leaving him handicapped. And after a few days of recovery, he can manage to start getting back to his daily routines: getting the daily newspaper, having lunch at a diner or pizzeria, and running chores for his wife Grace. It is on one of these trips that Sidney stumbles into "The Paper Palace", a curious paper shop that he has never noticed before (O’Connor, 2003).

Sidney pops into the stationery shop and meets its eccentric owner, M. R. Chang, a venture capitalist of sorts, who seeks opportunity for success in the writer-studded Brooklyn neighborhood. Stocked with the normal goods, Sidney finds one very interesting object in the shop, a blue Portuguese notebook that for some inexplicable reason holds a very powerful draw to him. He purchases the notebook and heads back home to resume his normal day-to-day activities, hoping to come up with an idea promising enough to grace its pages. Following the purchase, Sidney finds himself reinvigorated with the urge and need to write and the words pouring out of him at a pace he has not had since his accident. Could the newfound verve be due to the mysterious notebook? Sidney seems to think it has helped him, but can not believe that it has some kind of power over his writing. That is until he finds that Trause has been using the very same notebooks for his own novels. Sidney is very curious about the same interest in using blue notebooks, so he asks why (O’Connor, 2003).

Trause answers,

It doesn't mean anything, Sid. Except that you are a little off in the head. And I'm just as off as you are. We write books, don't we? What else can you expect from people like us? (p. 41)

\footnotetext{
4 "Chinese boxes" are a set of boxes of graduated size, each fitting inside the next larger box. In literature, a Chinese box structure refers to a novel or drama that is told in the form of a narrative inside a narrative (and so on), giving views from different perspectives.
} 
This paragraph tells us the underlying development track. Trause's answer is sort of hint of himself, of Sidney and of Auster. John Trause's health makes Sidney's wife Grace annoyed. And Sidney understands her anxiety because John is her "loving uncle." But her continuing anxiety becomes stronger and stronger because she is pregnant. And she is not sure if the fetus is Sidney's or John Trause's. After reconsideration, she decides to give birth to the baby. The tranquility is soon disturbed by John Trause's son who is addicted to drugs. He rushes into Sidney's house, quarrels with and hits Grace roughly, who is abortive after the violence. John Trause dies in his home. Sidney and Grace are lucky to find that they are still alive to lead a new and tranquil life.

This story is a first-degree story in that the story is about the "backbone" or "stem" of the whole novel, to which other information is added. The essence of fiction is narration, the recounting or telling of a sequence of events of actions. No matter what kind of novel it is, the author will inevitably give an account of the essential elements of fictions, which are the situation, characters, plot, structure and theme. The first-degree narrative, or Sidney's story, though not clearly put forward, has provided readers with the basis of the whole narration. It works as the framework of the whole novel, while readers cannot apprehend what Auster intends to indicate. It is for this reason that other degrees of narration should be added. If it is not for the adding of other important stories, the accomplishment of Sidney's story will appear to be pale, feeble and impossible, let alone the comprehension of the whole novel.

\section{B. Second-degree Structure and Third-degree Structure}

A second-degree structure is embedded in a first-degree structure and a third-degree structure is embedded in a second-degree structure. Both the second-degree structure and the third-degree structure are types of the Embedded Structure.

Embedded Structure is a kind of writing skill just like the Chinese boxes in that the author makes an outline of a story in the same way as the structure of Chinese boxes model (Manfred Jahn, 2005), that is, "tales within tales within tales." Just as Paul Auster(1988) says in an interview in The Art of Hunger, ... Chinese box, an infinite series of containers within containers. After all these stories are applied into the creation process of the novel, the stories within correspond to the body of the novel rather than merely a simple juxtaposition. All these accomplish the creation of a novel by affecting each other, thus to function as a whole.

From here on, Auster's Oracle Night separates time inside and out of Sidney's creation, describing Sidney's own life in equal parts, and the life of his characters. The second-degree structure is about the procedure of writing a novel on the magical "blue Portuguese notebook", that is, a story with the protagonist named Nick Bowen, who "works as an editor at a large New York publishing house, and is married to a woman named Eva" (p. 13). During the process of writing, the writer, Sidney, intrudes into the narrative to explain his procedures, and offers the reader alternative endings, which is an important and obvious feature of metafiction, for example, the uncertainty of Bowen's fate in the underground house. Readers would not know whether Nick could survive the accident. Still, within the novel of Oracle Night, there is another novel with the same title. The relationship between the two names and the contents is another point to be studied.

The second-degree narrative consists of several stories. In order to elucidate in a more clear way, the paper marks the stories in the following order.

Story 1 is fictional. "On the advice of the mentor, John Trause, Sidney appropriates the story of Flitcraft, a minor character from Dashiell Hammet's The Maltese Falcon as his first project. The theme of the Flitcraft story is how a random occurrence can completely alter the path of a person's life. Hammet's character holds a decent job and a good and perfect family, but one day he gives up everything and disappears after a near tragic accident as he is passing a construction site. Flitcraft realizes that one's life is dominated by nothing but chanciness. Random events are underneath everybody's daily life. Life will be deprived without any reason at any time. Both Sidney and Trause find Flitcraft's tale to be a compelling enough story with innumerable possibilities" (O'Connor, 2003).

Story 2 is also fictional. With this new blue notebook, Sidney creates his Flitcraft in the form of Nick Bowen, a high-profile New York book editor. According to Sidney's creation, Bowen has just received an unpublished manuscript named Oracle Night from the granddaughter of the late Sylvia Maxwell, a major literary figure. On his way home from work, Bowen is nearly beheaded by the dislodged head of stone gargoyle, thus comes the beginning of his Flitcraft story. Bowen thinks that he should be dead, although he is lucky to be alive. So he leaves New York as quickly as possible by the first flight, only taking some clothes and the copy of Oracle Night without guilt. "Those notebooks are very friendly, but they can also be cruel, and you have to watch out you don't get lost in them" (p. 40), warns Trause. And the notebook soon reveals its cruelty. Sidney sends off Bowen to Kansas City and sets him up with an odd man named Ed Victory, a newly retired taxi driver who lives in an underground bunker full of historical phonebooks. The apprenticeship between Bowen and Victory is soon set up, and Bowen spends his days helping out in the Bureau and obsessively reading and rereading Oracle Night. But then Sidney gets stuck. He has got Bowen bound in this bunker with nowhere to go, and he is using up the pages in the notebook. Is it possible that Sidney has subconsciously anticipated this whole affair, and entered them into his own created story? Auster takes this on as the key issue in Oracle Night.

Story 3, however, suggests a story of reality about John Trause's brother-in-law, Richard. Richard finds an old 3-D viewer with 3-D pictures in his garage, by which, he "remembered everything now" (p. 33), "everyone was there, his mother and father, his cousins, his aunts and uncles, his sister, his sister's friends" (p. 34), whom he meets by himself in 
the garage. But "the viewer didn't work", so he goes to ask John Trause for help. When John finally finds someone to repair it, Richard changes his mind and says "the past is past, and no matter how much time I spend with those pictures, I'm never going to get it back." (p. 36)

Story 4 is a fictional story about the time machine. In order to earn 5000 dollars, Sidney plans to write a drama. The story is about a man from the past and a woman from the mid-twenty-second century who meet each other by travelling through the Time Tunnel to the year of 1963. After that, the two try to stop the assassination of Kennedy but in vain. So "they destroyed their time machines and bury them in the meadow. Then with the sun rising before them, they walk off into the morning of November twenty-third, two young people who have renounced their pasts, preparing to face the future together.'(p. 113)

Normally, the order in which narrative events are presented in the text corresponds to their order of occurrence in the fictional world (Ehrlich, 1995, p.125). Thus, if one story is narrated before another one, readers will assume that the first story temporally precedes the latter one in the fictional world. Here, in Oracle Night, the author distorts the chronological order, but integrates stories with a recessive line to form a framework of the novel. Stories form a labyrinth, which lead readers into a new vista to experience the magic atmosphere, which provides possibility for the integration of the whole novel.

After the insertion of the second-degree narratives, now readers can obtain a clear understanding of the novel, apart from that stories are placed in randomness and some are irrelevant to the basic story. The first two narrative degrees tell readers that after recovery from fatal disease, Sidney regains the ability and interest of novel creation. He creates Bowen's story with the reference of The Maltese Falcon, which indicates that chanciness plays a very important role in one's life. In order to highlight this concept, Sidney narrates many stories paralleling Bowen's story. We never know what will happen accompanied with the thing we like to come across at will. Moreover, to enhance the chanciness of life, and to integrate the whole narration, Auster as well as Sidney continue to add another degree of narrative, hence coming the third-degree narrative.

There is also a story about one plot in the late Sylvia Maxwell's lost work Oracle Night, fictional about the future. Sidney puts it like this, "everything still had to be worked out concerning the plot, but I knew that it was supposed to be a brief philosophical novel about predicting the future, a fable about time." The story is about "Lemuel Flagg, a British lieutenant blinded by a mortar explosion in the trenches of World War I", "Flagg's blindness has given him the gift of prophecy." On the night before the wedding, Flagg has a spell of his bride Bettina who will betray him before the year is out, "unable to face the anguish that destiny has prepared for him, Flagg stabs himself in the heart and dies".

Another example is in Chapter 10 about Grace's strange dream about the experience of sexual relationship between the two. The experience is that they have had sex, and find that they are locked in a room and could not find a way out, which is similar to Bowen's fate in Sidney's manuscript in the blue notebook. The novel goes like this:

I know you never go into my workroom. But if you did, and if you happened to open the blue notebook I bought on Saturday, you'd see that the story I've been writing is similar to your dream. The ladder that goes down to an underground room, the library bookcase, the little bedroom at the back. My hero is locked in that room right now, and I don't know how to get him out. (p. 120-121)

This dream-telling can be regarded as a third-degree story, for it is a story within the second-degree story about Bowen. And it is just for the insertion of this degree of stories that the whole novel inclines to integrate and connect into integrity.

Auster's Oracle Night is one of those books that keep you wondering the whole process of writing. Does Sidney's reality reflect that of Bowen, or vice-versa? It is a difficult question to answer, considering that the book is three-layer deep in fictional characters (Orr-Bowen-Flitcraft), but certainly an fascinating one and Auster skillfully hints at his answer throughout the novel. Even when Bowen has left the scene and the novel concentrates on the events unfolding in Sidney's real life, we still can't help wondering "What does this have to do with Bowen?" and finally, "What does Bowen have to do with this?" The answers are never achieved, but what matters is that Auster keeps the reader thinking about the question.

\section{RELATIONS OF STRUCTURAL DEGREES}

Usually the relationship between such nested narratives is quite clear, "with the embedded narrative playing a clearly subsidiary role, simply providing one more item of narrative material for the large narrative in which it is embedded" (Zou, 2002, p.89). But the relationship between structural degrees is far more complicated than this.

Bal (1985) observes that when layers of narrative are related with each other, there are two possible relationships. "The embedded story can explain the primary story." (Bal, 1985, p.54) In this case, the relationship is made explicit by the actor narrating the embedded story. it is obvious that some embedded stories are used to explain the primary story of Sidney Orr and to make it plumper. The embedded stories may "resemble the primary story"; the explanation is usually left to the reader, or merely hinted at, in the fabula (Zou, 2002, p.101).

After reading, readers may find that the life experiences of Paul Auster, Sidney and Bowen have something in common: all the three are engaged in paperwork, disclosing that people's lives have command over occasionality. In accordance with similarities among the three, Auster creates Sidney with the same occupation and the same residency, bestowing him even his own literary affection. Again, Sidney characterizes Bowen in terms of himself, even confers 
upon him a wife with the characteristics of Sidney's. What is more, some innermost desire can not be satisfied in real life which, however, meets the rich soil in the novel, for instance, the desire to visit a prostitute and the desire to reckon if his wife steps out on her husband. The three-layered embedding can be regarded as another hidden clue that motivates the development of the plot.

Rimmon-Kenan (1983) discusses various functions hypodiegetic narratives (the stories told by fictional characters, or the inner structural degrees) may have related to the narratives within which they are embedded:

1. Actional functions: some hypodiegetic (embedded narrative) narratives maintain or advance the action of the first narrative (primary story) by the sheer fact of being narrated, regardless (or almost regardless) of their content...

2. Explicative function: the hypodiegetic level offers an explanation of the diegetic level, answering such questions as "What were the events leading to the present situation?"

3. Thematic function: the relations established between the hypodiegetic and the diegetic levels are those of analogy, i.e. similarity and contrast [...] (Rimmon-kenan, 1983; Zou, 2002)

Manfred Jahn (2005) also clarifies that the hypodiegetic level is the synonym of embedded narrative levels. In his classification, it contains the second-degree narratives and the third-degree narratives. Similarly, diegetic level is the synonym of embedding narrative level, which here means the first-degree narrative.

Embedded narratives help the completion of an actional integration. The first-degree narrative in the first structural degree works as an important element in the second and third-degree narratives in Embedded Structure. For instance, in Oracle Night, Sidney's stories, both fictional and factual, help to complete the novel as a mysterious metafiction. Some stories at different narrative degrees appear to be preposterous and irrelevant to the theme but indeed they are important ingredients that make the novel a mystery about "oracle".

Embedded structure serves as expositions. The inner-narratives provide information about events outside the primary story line of the outer narrative.

The structure can work as distraction. As Genette (1988, p.93) states, "So tell us a story while we're waiting for the rain to stop," which means that this structure can make the novel more colorful and in this way, more information and more stories can be absorbed to form a more complicated and meaningful novel. In Oracle Night, readers may find that some detailed information is omitted or put in other places rather than in a cause-and-effect order. Especially in the story of Bowen, readers have the strong desire to know what the next step is after his fleeing away, however, the inner narrator Sidney makes an acrobatic leap to make some comments on Bowen and his wife's anxiety in finding him. Also some stories of the second degree are inserted in this process. He enjoys the fun of readers' appetite, which receives the effect in two aspects: for one thing, it lures readers to continue the reading process; for another, the continuity of the plot is distracted.

Embedded structure also functions as obstruction in the continuity of the whole and bestows the narration with more ups and downs. Stories at different narrative degrees momentarily suspend the continuity of the first-degree narrative, often creating an effect of elevated suspense. If it is not for the turning up of Sylvia Maxwell, the disappearance of Bowen would not be so mysterious to Rosa, Bowen's wife, and the finding of Bowen would become flat and uninteresting. Also, if it is not for the dubious relationship between Trause and Grace, the outcome of Grace's destiny would be rather irrational.

Just like the relations between the first-degree structure and other structural degrees, the relationship between the second-degree structure and the third-degree structure shares the same functions. The third-degree narrative in this structural degree serves as important ingredient in the fulfillment of the plots in the second-degree structure. For instance, Grace's dream is similar to Sidney's plot, which indicates the theme of the novel in that the daily events are just coincidences. And the night Grace dreams the dream is just an "oracle night". We can not tell if there is any link between the two. Meanwhile, it breaks the continuity of the narration of the second-degree structure.

To be specific, the embedded structure in Oracle Night can be illustrated via the following diagram:

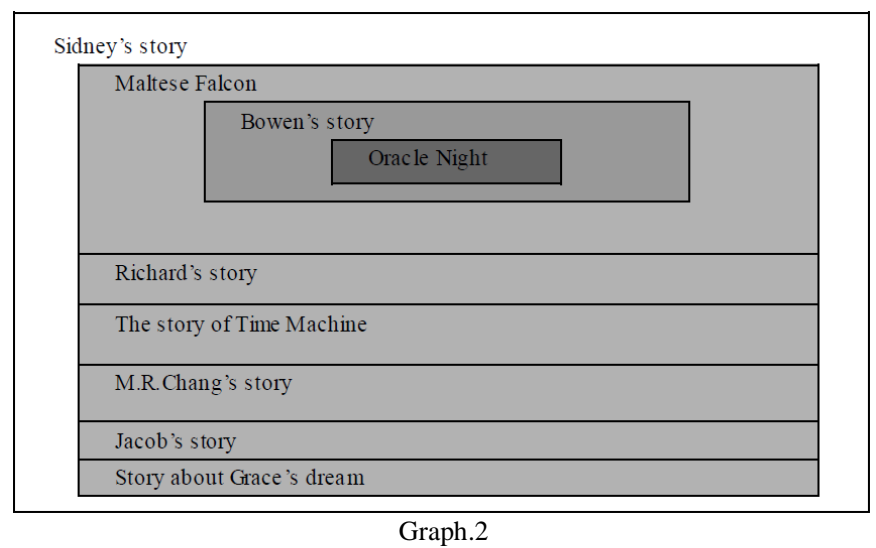

Simply put, the resemblance between the basic story and the embedded is like that of a mirror. As we know, Auster 
lives in the Cobble Hill section of Brooklyn, and the inner narrator Sidney as well as Bowen in the third degree structure all share the same residency with Auster. And this is one clue about the effect of principle of mirror image. More examples will be illustrated below. What is more, the embedded strand should be similar to the primary story or the embedding story, so it usually enhances the theme revealed by the primary story and thus makes what is described in the primary one more universal and reliable. A very telling example for this type is the graph 3 below:

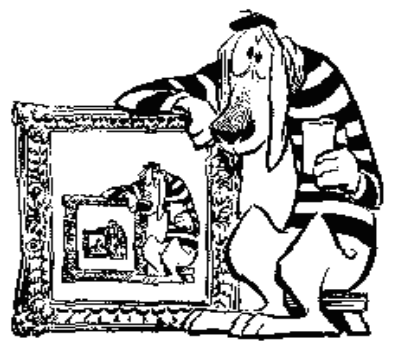

Graph.3

This kind of phenomenon is said to be "mise en abyme". (McHale, 1987). The infinite loop is achieved when the second and third-degree narratives embed its first-degree narrative.

It's also similar to something like Matisse's famous painting of a room in which a miniature version of the same paintings hangs on one of the walls. A famous example from Gide's work is The Counterfeiters where a character is engaged in writing a novel similar to the novel in which he appears (Rimmon-Kenan, 1983).

Oracle Night is a typical presentation of "mise en abyme". We can analyze this aspect from the very outside, that is to say, Paul Auster, who as a writer of postmodernist works, likes to write fictions with mysteries and suspense. And the protagonist of Oracle Night is also a writer who likes to create stories about the postmodernist society. And Sidney Orr's writing style is like that of Auster's, for it begins with the discovery of a mysterious notebook, and the notebook turns a man's life upside down in this compulsively tale. Also in the story of Sidney, there is another hero named Bowen who also has a lot to do with writing. In this story, there is another person named Sylvia Maxwell, who used to be a "first-rate novelist" who wrote Oracle Night, a novel with the same title as Auster's work. All these tell self-evidently the effect of "mise en abyme" of Oracle Night as a metafiction.

\section{REFERENCES}

[1] Auster, P. (2004). Oracle Night. New York: Henry Holt Co. Ltd. Auster, P. (1998). The Art of Hunger: Essays, Prefaces, Interviews. New York: Sun \& Moon Press.

[2] Bal, M. (1986). Narratology. Toronto: University of Toronto Press.

[3] Bal, M. (1981). Notes on Narrative Embedding. Poetics Today, 2, 41-59.

[4] Barth, J. (1984). "Tales within Tales within Tales". The Friday Book: Essay and Other Non-Fiction. New York: Putnam.

[5] Ehrlich, S. (1990). Point of view: A Linguistics Analysis of Literary Style. London and New York: Routledge.

[6] Genette, G. (1980). Narrative Discourse: An Essay in Method. New York: Cornell UP.

[7] Jahn, M. (2005). Narratology: A Guide to the Theory of Narrative. University of Cologne Press.

[8] Martin, B. (2008). Paul Auster's Postmodernity. New York \& London: Routledge.

[9] McHale, B. (1987). Postmodernist Fiction. New York and London: Methuen.

[10] Ni, Hui. (2012). Study of the Open Structure in Oracle Night as a Metafiction. Journal of Language Teaching and Research, 4,778-783.

[11] Ni, Hui \& Lian, Dawei. (2012). Study of the Fragmented Structure in Oracle Night as a Metafiction. Theory and Practice in Language Studies, 3, 540-546.

[12] Onega, S. (1996). "Structuralism and narrative poetics", in Patricia Waugh's Literary Theory \& Criticism.

[13] O'Connor, Michael. (2003). Oracle Night by Paul Auster. http://contemporarylit.about.com/od/fiction/fr/oracleNight.htm. (accessed 12/02/2013).

[14] Prince, G (1988). Narratology: The Form and Functioning of Narrative. Berlin, New York, Amsterdam.

[15] Prince, Gd. (2003). A Dictionary of Narratology. Lincoln: University of Nebraska Press.

[16] Rimmon-Kenan. Shlomith. (1983). Narrative Fiction, Contemporary Poetics. London \& New York: Methuen.

[17] Waugh, P. (1984). Metafiction: The Theory and Practice of Self-conscious Fiction. New York: Methuen.

[18] William, N. (1997). Frameworks: Narrative Levels and Embedded Narrative, New York: Peter Lang.

[19] Zou, Jie. (2002). A Study of Narrative and Embedded Structure. Hefei: University of Science \& Technology of China Press.

Hui Ni was born in Heze, Shandong, China in 1982. She received her M.A. degree in (English) pedagogy from Bohai University, China in 2009.

She is currently an assistant in the School of Foreign Languages, Heze University, Heze, China. Her research interests include contrastive teaching and literary criticism. She has published many research papers in domestic magazines. E.g. A Contrastive Study on Images of Woman between Chinese and Western Traditional Cultures (Qufu, Shandong: Modern Chinese, 2011). 